\title{
Effect of Financial Ratio on LQ45 2019 Stock Return
}

\author{
Peter Pratama ${ }^{1}$ Junino Jahja,** \\ ${ }^{1}$ Master of Management Program, Faculty of Economics and Business, Universitas Indonesia \\ *Corresponding author. Email: ninoj2@gmail.com
}

\begin{abstract}
Efficient Market Hypothesis states that stock price immediately reflects all available information, but evidence on delay in information absorption gave rise to the idea that current financial ratios may affect future stock price and return. This study aimed to determine whether financial ratios affect stock return in Indonesian market, represented by stocks in LQ45 2019 index, and to study factors that may cause deviation in this regard. We obtained panel data from stocks in LQ45 index of Indonesia Stock Exchange February-July 2019 and/or August 2019-January 2020, observed from December 2014 to December 2019. Independent variables were financial ratios, and dependent variables were quarterly and annual stock returns. Data were collected in June 2020. Single-stock analysis showed varying results with varying beta and adjusted R-squared values, with trend of PER and PBV being prominent factors. All-stocks analysis revealed negative influence of DY on annual return with poor adjusted R-squared value, suggesting that financial ratios were unable to universally explain stock returns. Additional analyses with information lag of 2-4 quarters showed varying results across quarters, among which were significant effects of ROE and NPM, suggesting delay in information absorption. We concluded that financial ratios affected LQ45 2019 stock return in stock-specific and lag-specific fashion, with no immediate effect on quarterly return of all stocks but significant effect of DY on annual return. PER, PBV, ROE, and NPM may have benefits for prediction depending on stocks and lag periods. Regardless, investors may still be able to predict stock return by single-stock analyses.
\end{abstract}

Keywords: Financial ratio, stock price, stock return, LQ45.

\section{INTRODUCTION}

Stocks have since long been one of the most common and intriguing forms of investment. The Indonesia Stock Exchange (IDX) recorded 92.8 million stock transactions worth 2,040.1 trillion Rupiah in 2018, an increase from 74.4 million stock transactions worth 1,809.6 trillion Rupiah in 2017 [1]. On the side of investors, stock is a precious yet common speculative investment. Predicting how the price would move is always a challenge to investors and a puzzle to economists until today [2]. On the side of company managers, stock is a precious source of corporate capital. Stock price reflects the image and value of the company, therefore management always strives to raise stock price. This will give positive buy signals for investors, increasing its price, and attracting more investors, completing a cycle that will benefit the company [3]. Knowing what factors could drive stock price movement is the interest of both investors and management: for investors, to speculate, and for the management, to gain a better position in the capital market.

Several factors potentially affect the fluctuation of stock price and return. Efficient Market Hypothesis
(EMH) attempted to explain how stock price immediately absorbs and reflects all available information, thus the information can no longer affect stock price $[3,4]$. In general, EMH is categorized into three forms based on the definition of "available information": 1) weak form (information on past stock transactions), 2) semi-strong form (all published information), and 3) strong form (all information including unpublished and internal secrets). Past studies generally agreed that the market is acceptably efficient in weak form and is not efficient in strong form. However, there are a lot of debates around the semistrong form efficiency. While it is believed that stock price is affected by fundamental information including financial ratios - the rate at which information is absorbed and reflected is subject to further study [3]. If the market is truly efficient, all available information would affect current stock price and no longer affect future price. However, if there is lag in that absorption, today's information would affect future stock price, thus will be beneficial in predicting stock return.

Various studies have attempted to prove the effect of financial ratios on stock return $[2,5,6]$. Several similar studies have also been conducted in the Indonesian 
market, though mostly studied specific business sector [7-16]. However, their results varied widely and did not obtain a consensus of which financial ratios have stronger effect on stock return. Additionally, preliminary search in the Scopus database did not find an updated study with 2019 data. Therefore, this study sought to determine whether financial ratios affect stock return in Indonesian market, represented by stocks in LQ45 2019 index, and to study factors that might cause deviation in this regard.

\section{LITERATURE REVIEW}

\subsection{Efficient Market Hypothesis (EMH)}

The weak form of EMH states that stock price immediately absorbs and reflects all information on past stock transactions in the market, i.e. price and volume, such that it no longer affects future price. It is called "weak form" because transaction information is the easiest to obtain, costless, and requires almost no effort, especially in the era of the internet. When this form of efficiency applies, technical analysis - which relies on pattern and trend of historical stock price - has no use in predicting stock prices and returns. Instead, they will fluctuate in the so-called "random walk". In general, the available evidence suggests that the market is at least efficient in its weak form, as otherwise every investor and fund manager would be able to obtain abundant returns.

The semi-strong form states that all published information will be immediately reflected and incorporated into the current stock price. If this form of efficiency applies, then fundamental analysis - which relies on published information, including financial reports and the financial ratios derived from those reports - will no longer be able to predict stock prices and returns. Until now, evidence is lacking regarding the semistrong form, especially in terms of the rate at which public information is incorporated into stock prices. As briefly explained earlier, we can expect three possibilities: 1) the market is completely not efficient in semi-strong form. In this case, the stock price would be inconsistent to financial ratios; 2) the market is efficient in semi-strong form. In this case, current financial ratios have affected current stock price and would not affect future stock price. 3) the market is not efficient, absorbing information (either all or selectively) at delayed rate. In this case, current financial ratios would affect future stock prices.

The strong form states that all existing information, including unpublished ones, will be immediately reflected and incorporated into the current stock price. Generally, the market is not efficient in strong form, therefore insider trading can gain considerable profit. This kind of trade is strictly regulated and monitored, with violations being punishable by law in most, if not all, stock exchanges across countries $[3,4]$.

\subsection{Financial Ratios}

The diverse characteristics and magnitude of stock emitters render financial comparison difficult. To simplify this process, analysts use financial ratios, which are comparisons of two or more financial measures from a company. Still, there are varying definitions of how financial ratios are calculated. The ones used in this study are as follows:

Table 1. Definition of Financial Ratios

\begin{tabular}{|c|c|}
\hline Financial Ratios & Formula \\
\hline $\begin{array}{l}\text { DER } \\
\text { Debt-to-Equity Ratio [17] }\end{array}$ & $\frac{\text { total liabilities }}{\text { total equity }}$ \\
\hline $\begin{array}{l}\text { DPR } \\
\text { Dividend Payout Ratio [3] }\end{array}$ & $\frac{\text { dividend }}{\text { net income }} \times 100 \%$ \\
\hline $\begin{array}{l}\text { EPS } \\
\text { Earning-per-Share [17] }\end{array}$ & $\frac{\text { net uncoms }}{\text { \# commonshares outotanding }}$ \\
\hline $\begin{array}{l}\text { PER or P/E } \\
\text { Price-to-Earning Ratio [17] }\end{array}$ & $\frac{\text { market price per share }}{\text { eaming - per - share }}$ \\
\hline $\begin{array}{l}\text { PBV } \\
\text { Price-to-Book Value Ratio [3] }\end{array}$ & $\begin{array}{l}\text { market walue per share } \\
\text { book walue per share }\end{array}$ \\
\hline $\begin{array}{l}\text { ROA } \\
\text { Return-on-Assets [17] }\end{array}$ & $\frac{\text { net income }}{\text { average total assets }}$ \\
\hline $\begin{array}{l}\text { ROE } \\
\text { Return-on-Equity [17] }\end{array}$ & $\frac{\text { net income }}{\text { average total equity }}$ \\
\hline $\begin{array}{l}\text { NPM } \\
\text { Net Profit Margin [17] }\end{array}$ & $\frac{\text { net income }}{\text { net rewenue }}$ \\
\hline $\begin{array}{l}\text { DY } \\
\text { Dividend Yield [17] }\end{array}$ & $\frac{\text { dividend per share }}{\text { market price per share }}$ \\
\hline
\end{tabular}

\section{METHODS}

This study used secondary panel data from stocks enlisted in LQ45 index of Indonesia Stock Exchange (IDX) during February-July 2019 and/or August 2019January 2020, a total of 48 companies whose stocks are considered as the most liquid in the market (Table 2). The list of stocks was obtained from the website of IDX, and all financial data including stock price were obtained from Thomson-Reuters EIKON. All data were obtained in June 2020 and observed in quarters, as financial reports are also released quarterly.

Observation period was December 2014 to December 2019 (5-years period, 20 quarters). This choice was based on scientific judgment and assumption; the COVID-19 pandemic that occurred in early March 2020 has caused a rapid and drastic fall in global stock prices, Indonesian included, which was 
Table 2. List of Sample Stocks

\begin{tabular}{|c|c|c|c|c|c|}
\hline No & Code & Company Name & No & Code & Company Name \\
\hline $\mathbf{1}$ & $\mathrm{ADHI}$ & Adhi Karya (Persero) Tbk. & 25 & ITMG & Indo Tambangraya Megah Tbk. \\
\hline 2 & ADRO & Adaro Energy Tbk. & 26 & JSMR & Jasa Marga (Persero) Tbk. \\
\hline 3 & AKRA & AKR Corporindo Tbk. & 27 & KLBF & Kalbe Farma Tbk. \\
\hline 4 & ANTM & Aneka Tambang Tbk. & 28 & LPPF & Matahari Department Store Tbk. \\
\hline 5 & ASII & Astra International Tbk. & 29 & MEDC & Medco Energi Internasional Tbk. \\
\hline 6 & BBCA & Bank Central Asia Tbk. & 30 & MNCN & Media Nusantara Citra Tbk. \\
\hline 7 & BBNI & Bank Negara Indonesia (Persero) Tbk. & 31 & PGAS & Perusahaan Gas Negara (Persero) Tbk. \\
\hline 8 & BBRI & Bank Rakyat Indonesia (Persero) Tbk. & 32 & PTBA & Bukit Asam Tbk. \\
\hline 9 & BBTN & Bank Tabungan Negara (Persero) Tbk. & 33 & PTPP & PP (Persero) Tbk. \\
\hline 10 & BMRI & Bank Mandiri (Persero) Tbk. & 34 & PWON & Pakuwon Jati Tbk. \\
\hline 11 & BRPT & Barito Pacific Tbk. & 35 & SCMA & Surya Citra Media Tbk. \\
\hline 12 & BSDE & Bumi Serpong Damai Tbk. & 36 & SMGR & Semen Indonesia (Persero) Tbk. \\
\hline 13 & CPIN & Charoen Pokphand Indonesia Tbk & 37 & SRIL & Sri Rejeki Isman Tbk. \\
\hline 14 & ELSA & Elnusa Tbk. & 38 & TKIM & Pabrik Kertas Tjiwi Kimia Tbk. \\
\hline 15 & ERAA & Erajaya Swasembada Tbk. & 39 & TLKM & Telekomunikasi Indonesia (Persero) Tbk. \\
\hline 16 & EXCL & XL Axiata Tbk. & 40 & TPIA & Chandra Asri Petrochemical Tbk. \\
\hline 17 & GGRM & Gudang Garam Tbk. & 41 & UNTR & United Tractors Tbk. \\
\hline 18 & HMSP & H.M. Sampoerna Tbk. & 42 & UNVR & Unilever Indonesia Tbk. \\
\hline 19 & ICBP & Indofood CBP Sukses Makmur Tbk. & 43 & WIKA & Wijaya Karya (Persero) Tbk. \\
\hline 20 & INCO & Vale Indonesia Tbk. & 44 & WSBP & Waskita Beton Precast Tbk. \\
\hline 21 & INDF & Indofood Sukses Makmur Tbk. & 45 & WSKT & Waskita Karya (Persero) Tbk. \\
\hline 22 & INDY & Indika Energy Tbk. & 46 & BTPS & $\begin{array}{l}\text { Bank Tabungan Pensiunan Nasional Syariah } \\
\text { Tbk }\end{array}$ \\
\hline 23 & INKP & Indah Kiat Pulp \& Paper Tbk. & 47 & CTRA & Ciputra Development Tbk \\
\hline 24 & INTP & Indocement Tunggal Prakarsa Tbk. & 48 & JPFA & Japfa Comfeed Indonesia Tbk \\
\hline
\end{tabular}

marked by the fall of Jakarta Composite Index by $16.8 \%$ and the LQ45 index by $-21.4 \%$ throughout March 2020. We believe that the closing stock price of March 2020 is no longer able to accurately describe the relationship we are looking for. Therefore, the closing price of the previous quarter, i.e. December 2019, will be used. Five-year observation period was based on average observation period in previous Indonesian studies (4.80 years).

Mathematical models used in this study follow those commonly used in stock price predictive studies, as follows:

- Individual variabel model, which is a common predictive regression model $[2,6,18,19]$ :

$$
y_{i, t+h}=\alpha_{i}+\beta_{i} x_{i, t}+u_{i, t+h}
$$

with:

$t+h=$ forecasting period ( $h$ periods in future).

$y_{i, t+h}=$ forecasted dependent variable on period $t+h$

$\alpha_{i}=$ intercept of independent variable $x_{i, t}$

$\beta i=$ coefficient/slope of independent variable $x_{i, t}$

$x_{i, t}=$ individual financial ratio on period $t$ $u_{i, t+h}=$ regression residual

- Combined variable model, adapted from Jordan et al. [18] and Rapach et al. [19]:

$y_{c, t+h}=\alpha_{c}+\left(\beta_{1}^{s} x_{1, t}+\cdots+\beta_{n}^{s} x_{n, t}\right)+u_{c, t+h}$

with:

$t+h=$ forecasting period ( $h$ periods in future)

$y_{i, t+h}=$ value of dependent variable on period $t+h$

$\alpha_{c}=$ intercept for combination model

$\beta^{\prime} i=$ coefficient/slope of independent variable $x_{i, t}$ in combination model

$x_{i, t}=$ individual financial ratio on period $t$

$u_{c, t+h}=$ regression residual

Both models were applied to single-stocks for preliminary analysis and then to all-stocks. Single-stock analyses employed individual regression on each stock as time-series data. All-stocks analysis used panel data regression; in determining between fixed, random, or pooling model, this study used Chow test (pooling vs fixed), Lagrange multiplier test with Breusch-Pagan 
methods (pooling vs random), and Hausman test (random vs fixed) [20]. The study will use lag period (h) of 1 quarter, with additional analyses of 2-4 quarters lag to explain the initial findings by capturing the potential effects up to one year period.

Independent variables used were DER, DPR, EPS, PER, PBV, ROA, ROE, NPM, and DY. Dependent variables were stock return $(\mathrm{SR})$, excess return (ER, based on yield rate of Indonesia 3-months bond), and abnormal return (AR, compared to the rate of IDX Composite index), expressed quarterly (SR-Q, ER-Q, AR-Q). Annual returns (SR-Y, ER-Y, AR-Y) would be added as additional analysis. Stock prices used to calculate returns were adjusted to dividends.

Statistical analysis was performed with R Project for Statistical Computing version 4.03. Statistical significance was assumed on p-value of less than 0.05. Multicollinearity was determined by using Variable Inflation Factor (VIF) with score of 5 as threshold [21]. Heteroskedasticity and autocorrelation were corrected using Heteroskedasticity-and-Autocorrelation Consistent (HAC) standard errors, with NeweyWest method (lag $=1-\sqrt[3]{0.75 T}$ with $\mathrm{T}=$ number of observations, prewhite $=$ FALSE, adjust $=$ TRUE) for time-series data [22] and group clustering method (with estimation type $=$ "HC3") for panel data [20].

\section{RESULTS AND DISCUSSION}

Data from 48 stocks as described in Table 2 were collected on June 23, 2020. Total of 929 observations were obtained, with 20 observations each except WSBP (8 observations) and BTPS (1 observation). Due to lack of observations, BTPS must be excluded from analysis, while WSBP could not undergo combined variable model analysis.

Preliminary analysis on single-stocks with both individual and combined variable models showed widely-varied results between stocks and across lag periods, with equally varying beta values, and therefore did not show any consensus of which financial ratio can better explain stock price fluctuation. Adjusted Rsquared values for individual and combined variable models were $2.09 \%-82.97 \%$ and $0-95.82 \%$, respectively, suggesting that financial ratios affected each stock in different directions and magnitude.

The beta value in our single-stock analysis (Table 3) may give an insight into Indonesian stock market preference. DER in the analysis had varying beta with negative average. Theoretically, a higher DER means lower proportion of a firm's value owned by stockholders, therefore the stock price and return should be lower (negative effect). However, we also found some positive DER, possibly due to market's positive response on higher expected performance in leveraged firms. The DPR and DY effects in this study could not be attributed to a decrease of intrinsic stock value and return due to dividend (as the returns were already adjusted to dividends), and is thought to be either: 1) preference of Indonesian investors to either dividend gain (positive effect, as in quarterly return analysis) or capital gain (negative effect, as what was found in annual return analysis), or 2) market's varying expectation on the growth of companies which distribute dividend, or 3) tendency that only matured companies (relatively lower stock return) distribute dividends (relatively higher DPR and DY). PER and PBV are both market valuation measures; positive PER and PBV (as in annual return analysis) theoretically indicate high return on highly valued stocks, while negative value (as in quarterly return analysis) might imply low stock return on overvalued stocks. EPS, ROA, ROE, and NPM are equally performance measures but showed different average beta values; positive effects might show higher stock returns on higher performance companies (mainly in annual return analysis), while negative effects might indicate lower stock return on matured companies (especially in quarterly return analysis) [3,23].

We observed a particular trend in the number of stocks affected by each financial ratio in individual variable model (see Table 4 for quarterly returns and Table 5 for annual returns). When returns were calculated quarterly (short term), PER and PBV tended to have significant influence on more stocks in 1-quarter lag period $(h=1)$. There was fewer influence on longer lag periods, suggesting that information from PER and PBV tended to be absorbed relatively quickly, but incompletely, by stock prices and therefore still had weak long-term effects. Conversely, if the returns were

Table 3. Average Beta Values in Single Stock, Individual Variable Analysis, 1-Quarter Lag Period

\begin{tabular}{|l|r|r|r|r|r|r|r|r|r|}
\hline Returns & DER & DPR & EPS & PER & PBV & ROA & ROE & NPM & DY \\
\hline SR-Q & -0.431 & 0.042 & -0.013 & -0.049 & -0.058 & 3.042 & -1.091 & -11.601 & 18.773 \\
\hline ER-Q & -0.434 & 0.042 & -0.014 & -0.049 & -0.058 & 0.619 & -1.105 & -11.516 & 18.729 \\
\hline AR-Q & -0.079 & -0.220 & -0.011 & -0.046 & -0.040 & 6.128 & 1.138 & -6.930 & 13.186 \\
\hline SR-Y & -0.118 & -1.619 & -0.011 & 0.018 & 0.008 & 21.078 & 5.659 & -9.420 & -39.500 \\
\hline ER-Y & -0.250 & -1.615 & -0.011 & 0.027 & 0.008 & 21.044 & 5.655 & -9.320 & -39.626 \\
\hline AR-Y & 0.104 & -0.625 & -0.014 & 0.008 & 0.034 & 28.489 & 5.621 & -6.106 & -43.638 \\
\hline
\end{tabular}


Table 4. Number of Stocks Affected by Respective Financial Ratio in Single Stock, Individual Variable Analysis, Quarterly Return

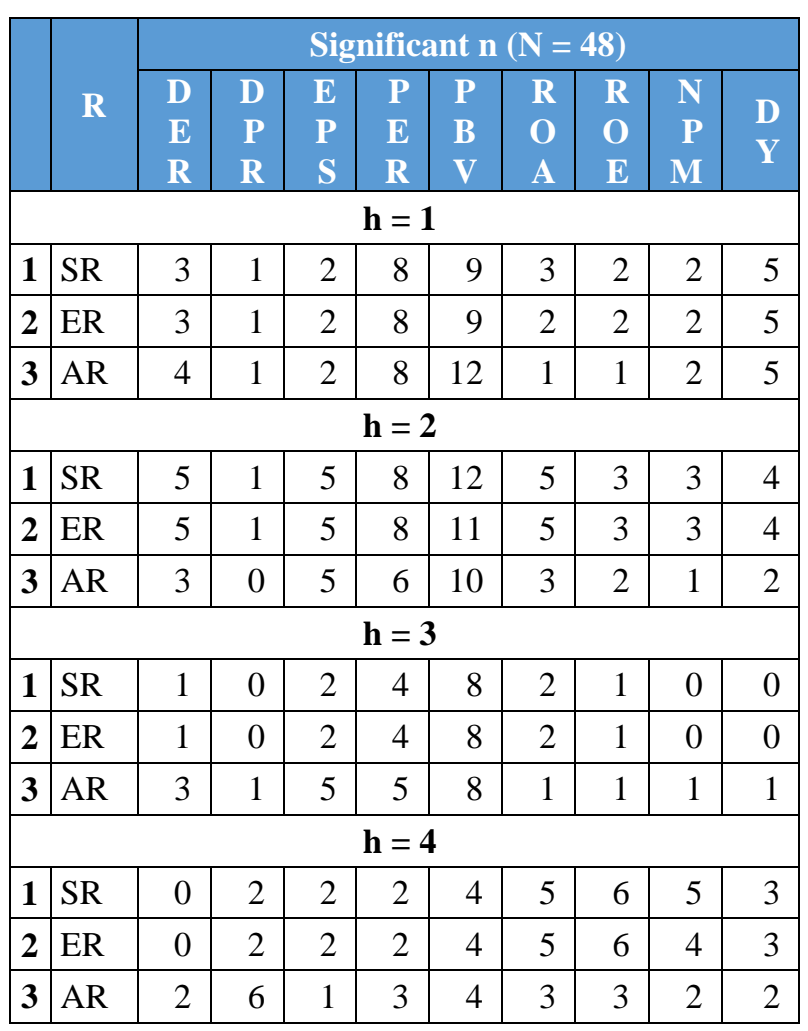

Table 5. Number of Stocks Affected by Respective Financial Ratio in Single Stock, Individual Variable Analysis, Annual Return

\begin{tabular}{|c|c|c|c|c|c|c|c|c|c|c|}
\hline & \multirow{4}{*}{$\mathbf{R}$} & \multicolumn{9}{|c|}{ Significant $\mathrm{n}(\mathrm{N}=48)$} \\
\hline & & $\bar{D}$ & $\bar{D}$ & $\bar{E}$ & $\bar{P}$ & $\mathbf{P}$ & $\overline{\mathbf{R}}$ & $\overline{\mathbf{R}}$ & $\mathbf{N}$ & $\bar{D}$ \\
\hline & & $\mathbf{E}$ & $\mathbf{P}$ & $\mathbf{P}$ & $\mathbf{E}$ & $\mathbf{B}$ & $\mathbf{O}$ & $\mathbf{O}$ & $\mathbf{P}$ & $\mathbf{Y}$ \\
\hline & & $\mathbf{R}$ & $\mathbf{R}$ & $\mathbf{S}$ & $\mathbf{R}$ & $\mathbf{V}$ & $\mathbf{A}$ & $\mathbf{E}$ & $\mathbf{M}$ & \\
\hline \multicolumn{11}{|c|}{$h=1$} \\
\hline 1 & SR & 8 & 9 & 11 & 8 & 6 & 15 & 16 & 14 & 16 \\
\hline 2 & ER & 9 & 9 & 11 & 9 & 7 & 15 & 16 & 14 & 16 \\
\hline 3 & AR & 10 & 11 & 10 & 10 & 11 & 14 & 15 & 18 & 13 \\
\hline \multicolumn{11}{|c|}{$\mathbf{h}=\mathbf{2}$} \\
\hline 1 & SR & 7 & 6 & 10 & 10 & 4 & 9 & 13 & 11 & 11 \\
\hline 2 & ER & 7 & 7 & 10 & 9 & 4 & 9 & 14 & 13 & 11 \\
\hline 3 & AR & 9 & 10 & 12 & 13 & 7 & 15 & 13 & 13 & 9 \\
\hline \multicolumn{11}{|c|}{$\mathbf{h}=\mathbf{3}$} \\
\hline 1 & SR & 9 & 8 & 15 & 15 & 14 & 7 & 11 & 11 & 4 \\
\hline 2 & ER & 9 & 8 & 15 & 15 & 15 & 7 & 11 & 11 & 3 \\
\hline 3 & AR & 8 & 8 & 15 & 14 & 14 & 12 & 13 & 14 & 6 \\
\hline \multicolumn{11}{|c|}{$h=4$} \\
\hline 1 & SR & 9 & 9 & 17 & 16 & 36 & 13 & 13 & 19 & 10 \\
\hline 2 & ER & 8 & 9 & 17 & 16 & 36 & 14 & 13 & 18 & 9 \\
\hline 3 & AR & 9 & 9 & 19 & 18 & 36 & 17 & 14 & 21 & 12 \\
\hline
\end{tabular}

quarters lag period than in shorter lag periods. This implied the opposite trend from the quarterly-return analysis. By examining per-stock analysis we found that the stocks affected by PBV/PER on quarterly returns were different than the ones affected on annual return. However, we could summarize that PBV and PER had greater tendency to influence stocks individually, compared to other financial ratios. The combined variable model displayed similar trend, but it notably resulted in multiple multicollinearities. We did not correct these problems further as the results were too varying between stocks and regardless were part of preliminary analyses.

All-stocks analysis with individual variable model showed shifting significant financial ratios to stock returns across quarter lag (Table 6). On the quarterly returns, at 1-quarter lag only DY affected AR, with no significant effect on longer lag periods. On 2-quarters lag the effect of NPM emerged (with weaker effect on 3- and 4-quarters lag) along with negligible effect of DER. This suggested that there was delay in information absorption of NPM. We also found statistically significant yet negligible effect of EPS (beta value of 0.000 after rounding to 3 decimals). When analyzing annual returns (Table 7), DY emerged as significant factor on 2-quarters lag with weaker effect on 3-quarters lag, suggesting delayed information absorption. Again, we observed delayed effect of NPM on 3- and 4quarters lag, along with significant yet negligible effect of PBV on 2-quarters lag.

Final analysis used combination variable model on all-stocks, which obtained similar yet different results. At 1-quarter lag period, on quarterly returns (Table 8) we found negligible effect of EPS and PBV, with negative adjusted R-squared value (interpreted as zero) which implied that no financial ratio affected return of all-stocks on quarterly basis. In annual return analysis (Table 9), we found strong negative effect of DY but also with very low adjusted R-squared value (2.02\%$2.54 \%$ ). Additional analyses with extended lag periods showed delayed effect of ROE and NPM on quarterly returns, along with delayed effect of EPS (negligible) and ROE on annual return.

An important note on all-stocks analyses was the very low adjusted R-squared value, ranging $-0.10 \%-$ $1.86 \%$ on individual variable model and $-3.99 \%-2.54 \%$ on combined variable model. This implied that more than $97 \%$ variation of all-stocks returns were not explained by financial ratios in both models. Considering the fact that we could obtain reasonably high adjusted $\mathrm{R}$-squared value on some stocks in singlestock analysis, the low R-squared values on all-stocks analysis might be caused by idiosyncratic factors, i.e. extreme variation between individual stocks.

calculated annually PBV affected more stocks in 4- 
Table 6. Values of Beta in All-stocks Analysis, Individual Variable Model, Quarterly Return

\begin{tabular}{|c|c|c|c|c|c|c|}
\hline & $\mathbf{R}$ & DER & EPS & PBV & NPM & DY \\
\hline \multicolumn{7}{|c|}{$h=1$} \\
\hline 1 & SR & & $0.000 *$ & & & \\
\hline 2 & ER & & $0.000 *$ & & & \\
\hline 3 & AR & & $0.000 *$ & & & $-0.697 *$ \\
\hline \multicolumn{7}{|c|}{$h=2$} \\
\hline 1 & SR & $-0.001 *$ & $0.000 *$ & & $-0.193 * *$ & \\
\hline 2 & ER & & $0.000 *$ & & $-0.193 * *$ & \\
\hline 3 & AR & & $0.000 *$ & & $-0.182 *$ & \\
\hline \multicolumn{7}{|c|}{$\mathbf{h}=\mathbf{3}$} \\
\hline 1 & SR & & $0.000 *$ & & $-0.165 *$ & \\
\hline 2 & ER & & $0.000 *$ & & $-0.165 *$ & \\
\hline 3 & AR & & $0.000 *$ & & $-0.154 *$ & \\
\hline \multicolumn{7}{|c|}{$h=4$} \\
\hline 1 & SR & & $0.000 *$ & & $-0.173 *$ & \\
\hline 2 & ER & & $0.000 *$ & & $-0.173^{*}$ & \\
\hline 3 & AR & & $0.000 *$ & & $-0.166 *$ & \\
\hline
\end{tabular}

Table 7. Values of Beta in All-stocks Analysis, Individual Variable Model, Annual Return

\begin{tabular}{|c|c|c|c|c|c|c|}
\hline & $\mathbf{R}$ & DER & EPS & PB V & NPM & DY \\
\hline \multicolumn{7}{|c|}{$h=1$} \\
\hline 1 & SR & & & & & \\
\hline 2 & ER & & & & & \\
\hline 3 & AR & & & & & \\
\hline \multicolumn{7}{|c|}{$h=2$} \\
\hline 1 & SR & & $0.000 *$ & $0.000 *$ & & $-9.192 * * *$ \\
\hline 2 & ER & & $0.000^{*}$ & $0.000 *$ & & $-9.211^{* * *}$ \\
\hline 3 & AR & & $0.000 *$ & $0.000 *$ & & $-8.572 * * *$ \\
\hline \multicolumn{7}{|c|}{$\mathbf{h}=\mathbf{3}$} \\
\hline 1 & SR & & & & $-1.023 *$ & $-5.488 *$ \\
\hline 2 & ER & & & & $-1.024 *$ & $-5.511 *$ \\
\hline 3 & AR & & & & & $-5.410 *$ \\
\hline \multicolumn{7}{|c|}{$h=4$} \\
\hline 1 & SR & & & & & \\
\hline 2 & ER & & & & $-0.969 *$ & \\
\hline 3 & AR & & & & & \\
\hline
\end{tabular}

$* \mathrm{p}<0,05 ; * * \mathrm{p}<0,01 ; * * * \mathrm{p}<0,001$

Only significant beta values are displayed.
Table 8. Values of Beta in All-stocks Analysis, Combined Variable Model, Quarterly Return

\begin{tabular}{|l|l|l|l|l|l|l|}
$\mathbf{R}$ & EPS & PBV & ROE & NPM & DY & Adj. R $^{2}$ \\
\hline
\end{tabular}

\begin{tabular}{|c|c|c|c|c|c|c|}
\hline & \multicolumn{6}{|c|}{$h=1$} \\
\hline 1 & SR & $0.000 *$ & & & & $-0.08 \%$ \\
\hline 2 & ER & $0.000 *$ & & & & $-0.08 \%$ \\
\hline 3 & AR & $0.000 * *$ & $0.000 *$ & & & $-3.99 \%$ \\
\hline \multicolumn{7}{|c|}{$h=2$} \\
\hline 1 & SR & $0.000 * *$ & & & $-0.150 *$ & $1.07 \%$ \\
\hline 2 & ER & $0.000 * *$ & & & $-0.150^{*}$ & $1.07 \%$ \\
\hline 3 & AR & $0.000 * *$ & & & $-0.194 * *$ & $1.30 \%$ \\
\hline \multicolumn{7}{|c|}{$h=3$} \\
\hline 1 & SR & $0.000 *$ & & $-0.012 *$ & & $0.86 \%$ \\
\hline 2 & ER & $0.000 *$ & & $-0.012 *$ & & $0.86 \%$ \\
\hline 3 & AR & $0.000 *$ & & $-0.016 * *$ & & $0.80 \%$ \\
\hline \multicolumn{7}{|c|}{$h=4$} \\
\hline 1 & SR & $0.000 *$ & & $-0.018 * * *$ & $-0.154 *$ & $1.39 \%$ \\
\hline 2 & ER & $0.000 *$ & & $-0.018 * * *$ & $-0.154 *$ & $1.40 \%$ \\
\hline 3 & AR & $0.000 *$ & & $-0.015^{*}$ & $-0.150 *$ & $1.28 \%$ \\
\hline
\end{tabular}

$* \mathrm{p}<0,05 ; * * \mathrm{p}<0,01 ; * * * \mathrm{p}<0,001$

Only significant beta values are displayed.

Table 9. Values of Beta in All-stocks Analysis, Combined Variable Model, Annual Return

\section{\begin{tabular}{l|l|l|l|l|l|l|}
$\mathbf{R}$ & EPS & PBV & ROE & NPM & DY & Adj. $\mathbf{R}^{2}$
\end{tabular}}

\begin{tabular}{|l|l|l|l|l|l|l|l|}
\hline \multicolumn{9}{|c|}{$\mathbf{h = 1}$} \\
\hline $\mathbf{1}$ & SR & & & & & $-13.950 * * *$ & $2.54 \%$ \\
\hline $\mathbf{2}$ & ER & & & & & $-13.972 * * *$ & $2.53 \%$ \\
\hline $\mathbf{3}$ & AR & & & & & $-12.582 * * *$ & $2.02 \%$ \\
\hline
\end{tabular}

$\mathbf{h}=\mathbf{2}$

\begin{tabular}{|l|l|l|l|l|l|l|l|}
\hline $\mathbf{1}$ & $\mathrm{SR}$ & & & & & $-9.481 * * *$ & $1.67 \%$ \\
\hline $\mathbf{2}$ & $\mathrm{ER}$ & & & & & $-9.522 * * *$ & $1.67 \%$ \\
\hline $\mathbf{3}$ & $\mathrm{AR}$ & & & & & $-8.610 * *$ & $1.47 \%$ \\
\hline
\end{tabular}

$\mathbf{h}=\mathbf{3}$

\begin{tabular}{|l|l|l|l|l|l|l|l|}
\hline $\mathbf{1}$ & SR & $0.000 *$ & & & & & $1.03 \%$ \\
\hline $\mathbf{2}$ & ER & $0.000 *$ & & & & & $1.02 \%$ \\
\hline $\mathbf{3}$ & AR & $0.000 *$ & & & & & $0.93 \%$ \\
\hline
\end{tabular}

$h=4$

\begin{tabular}{|l|l|l|l|l|l|l|l|}
\hline $\mathbf{1}$ & SR & $0.000 *$ & & & & & $2.51 \%$ \\
\hline $\mathbf{2}$ & ER & $0.000 *$ & & & & & $2.51 \%$ \\
\hline $\mathbf{3}$ & AR & $0.000 *$ & & $-0.054 * *$ & & & $2.30 \%$ \\
\hline
\end{tabular}

$* \mathrm{p}<0,05 ; * * \mathrm{p}<0,01 ; * * * \mathrm{p}<0,001$

Only significant beta values are displayed. 
Our findings were not consistent with the Efficient Market Hypothesis, which states that stock price immediately reflects all available information [3]. Instead, this study found that no ratio actually affected all stocks, and likewise no stock was affected by all ratios; each stock had its own varying "preference" for financial ratios, which might explain the low adjusted $\mathrm{R}$-squared values in all-stocks analysis. Additionally, we found varying results across lag periods between the observed stock price and the financial ratios. If information were absorbed immediately, there should not be any significant result on later quarters, as all information should have been absorbed and fully reflected on the same quarter or at the least on 1-quarter lag (due to financial ratios and reports being published 1-2 months into each period). Instead, this study observed some significant ratios that only affected returns after lag of two or more quarters.

Compared to most previous studies in Indonesian Stock Exchange which used sectoral stocks [7-9,12,1416] or LQ45 on annual analysis [13], this study used LQ45 stocks on quarterly basis which was thought to cause the highly varying results between stocks. Adjusted R-squared value obtained in other studies varied between $45.93 \%-98.23 \%[8,9,11,13,14,16]$, but some also found similarly low value of $4.42 \%-12.96 \%$ $[10,12,15]$. However, the trend found in this study, i.e. effects of PER, PBV, DY, ROE, and NPM to stock returns, was also found in previous studies.

The limitation of this study includes the use of relatively small sample (48 companies) which might not actually represent all 634 stocks in IDX (in Q2 2019). Additionally, the use of LQ45 stocks resulted in diverse business sectors and characteristics which might contribute to varying results between stocks. Quarterly analysis had both advantage and disadvantage in this study; it allowed the study to capture changes in the smallest possible time window (as financial ratios were published quarterly along with financial reports), but at the same time it might cause bias due to financial reports being published 1-2 months late in each period. Lastly, the use of 9 financial ratios might be insufficient to explain stock price fluctuations, and additional factors such as beta of stock and market capitalization [24], or external variables such as GDP or inflation rate might be beneficial in future studies.

\section{CONCLUSION}

Financial ratios affected LQ45 2019 stock return in stock-specific and lag-specific fashion, with no immediate effect on quarterly return of all stocks but significant effect of DY on annual return. PER, PBV, ROE, and NPM may have benefits for prediction depending on stocks and lag periods. The cause of nosignificance was idiosyncratic factors, i.e. variation of stock and firm characteristics; each stock absorbs and reflects different financial ratios at different rates, which cannot be explained within the limits of this study and were thought to be caused by investor behavior. This study showed that the Efficient Market Hypothesis did not apply to observed stocks. Investors may still be able to predict LQ45 stock return on various precision by single-stock analyses. Additionally, company management should exercise caution in determining dividend payment, as such policies will affect DY, which in turn may negatively affect stock price and return.

\section{AUTHORS' CONTRIBUTIONS}

Peter Pratama contributed to the main idea, drafts, methods, and analyses. Junino Jahja guided throughout the whole process, refined the idea, drafts, methods, analyses, and performed final checks.

\section{REFERENCES}

[1] Bursa Efek Indonesia. IDX fact book 2019 2019.

https://www.idx.co.id/media/4648/20181218_fb -2018.pdf.

[2] Devpura N, Narayan PK, Sharma SS. Is stock return predictability time-varying? J Int Financ Mark Institutions Money 2018;52:152-72. https://doi.org/10.1016/j.intfin.2017.06.001.

[3] Ross SA, Westerfield R, Jaffe J, Jordan B. Corporate finance. 11th ed. New York: McGraw-Hill Education; 2016.

[4] Bodie Z, Kane A, Marcus AJ, Mohanty P. Investments. 10th ed. New York: McGraw-Hill Education; 2017.

[5] Rangvid J, Schmeling M, Schrimpf A. Dividend predictability around the world. J Financ Quant Anal 2014;49:1255-77. https://doi.org/10.1017/S0022109014000477.

[6] Westerlund J, Narayan P. A random coefficient approach to the predictability of stock returns in panels. J Financ Econom 2015;13:605-64. https://doi.org/10.1093/jjfinec/nbu003.

[7] Utomo HS. Analisis hubungan rasio keuangan dengan imbal hasil saham (studi kasus pada sektor industri barang konsumsi di Bursa Efek Indonesia) [Unpublished master's thesis]. Faculty of Social and Political Sciences, Universitas Indonesia, 2011.

[8] Handono T. Analisis pengaruh rasio keuangan terhadap indeks harga saham individu (studi 
kasus pada delapan bank terbesar) [Unpublished master's thesis]. Facuilty of Economics and Business, Universitas Indonesia, 2011.

[9] Ayuningtiyas A. Analisis pengaruh premi risiko pasar, ukuran perusahaan, rasio book-to-market, dan momentum terhadap excess return saham per sektor industri yang terdaftar di BEI periode 2009-2013 [Unpublished master's thesis]. Faculty of Economics and Business, Universitas Indonesia, 2013.

[10] Ariapurwo D. Analisis hubungan rasio perusahaan terhadap return saham pada perusahaan-perusahaan dalam Indonesia Sharia Stock Index (ISSI) periode 2011-2012 [Unpublished master's thesis]. Faculty of Economics and Business, Universitas Indonesia, 2014.

[11] Nurmega C. Analisis pengaruh rasio likuiditas, rasio solvabilitas, rasio perputaran, rasio profitabilitas, dan rasio nilai pasar terhadap indeks harga saham individu saham-saham kelompok LQ45 [Unpublished bachelor's thesis]. Faculty of Economics and Business, Universitas Indonesia, 2014.

[12] Nalurita F. The effect of profitability ratio, solvability ratio, market ratio on stock return. Bus Entrep Rev 2017;15:73. https://doi.org/10.25105/ber.v15i1.2080.

[13] Satryo AG, Rokhmania NA, Diptyana P. The influence of profitability ratio, market ratio, and solvency ratio on the share prices of companies listed on LQ 45 index. Indones Account Rev 2017;6:55.

https://doi.org/10.14414/tiar.v6i1.853.

[14] Medyawati H, Yunanto M. Factors determining stock returns in property, real estate and construction companies in Indonesia. Int J Glob Small Bus 2017;9:3-19. https://doi.org/10.1504/IJGSB.2017.084707.

[15] Zaini VI, Sadalia I, Fachrudin KA. The effect of external and internal factors on stock return with price to book value as moderation variables in banking companies in Indonesia stock exchange. Int J Sci Technol Res 2018;7:77-82.

[16] Endri E, Dermawan D, Abidin Z, Riyanto S. Effect of financial performance on stock return: Evidence from the food and beverages sector. Int J Innov Creat Chang 2019;9:335-50.

[17] Libby R, Libby PA, Hodge F. Financial accounting. 9th ed. New York: McGraw-Hill Education; 2018.

[18] Jordan SJ, Vivian A, Wohar ME. Forecasting market returns: Bagging or combining? Int $\mathbf{J}$ Forecast 2017;33:102-20. https://doi.org/10.1016/j.ijforecast.2016.07.003.
[19] Rapach DE, Strauss JK, Zhou G. Out-of-sample equity premium prediction: Combination forecasts and links to the real economy. Rev Financ Stud 2010;23:821-62. https://doi.org/10.1093/rfs/hhp063.

[20] Croissant Y, Millo G. Panel data econometrics with R. Oxford: Wiley; 2019.

[21] James G, Witten D, Hastie T, Tibshirani R. An introduction to statistical learning: With applications in R. New York: Springer Science \& Business Media; 2013.

[22] Hanck C, Arnold M, Gerber A, Schmelzer M. Introduction to econometrics with R. Essen: University of Duisburg-Essen; 2019.

[23] Higgins RC. Analysis for financial management. Boston, Mass.: McGraw-Hill Education; 2016.

[24] Fama EF, French KR. A five-factor asset pricing model. J Financ Econ 2015;116:1-22. https://doi.org/10.1016/j.jfineco.2014.10.010. 